The University of Akron

\title{
IdeaExchange@UAkron
}

Proceedings from the Document Academy

University of Akron Press Managed

December 2016

\section{A Note on Resilience Perspectives in Public Library Research: Paths Towards Research Agendas}

Andreas Vårheim

Department of Language and Culture, UIT The Arctic University of Norway in Tromsø, andreas.varheim@uit.no

Please take a moment to share how this work helps you through this survey. Your feedback will be important as we plan further development of our repository.

Follow this and additional works at: https://ideaexchange.uakron.edu/docam

Part of the Civic and Community Engagement Commons, and the Library and Information Science Commons

\section{Recommended Citation}

Vårheim, Andreas (2016) "A Note on Resilience Perspectives in Public Library Research: Paths Towards Research Agendas," Proceedings from the Document Academy: Vol. 3 : Iss. 2 , Article 12.

DOI: https://doi.org/10.35492/docam/3/2/12

Available at: https://ideaexchange.uakron.edu/docam/vol3/iss $2 / 12$

This Conference Proceeding is brought to you for free and open access by University of Akron Press Managed at IdeaExchange@UAkron, the institutional repository of The University of Akron in Akron, Ohio, USA. It has been accepted for inclusion in Proceedings from the Document Academy by an authorized administrator of

IdeaExchange@UAkron.For more information, please contact mjon@uakron.edu, uapress@uakron.edu. 


\section{Introduction}

In most cases, definitions of resilience are related to the ability to bounce back after shocks (Norris, Stevens, Pfefferbaum, Wyche, \& Pfefferbaum, 2008). Resilience theory has been actualized in the past few years around dramatic and abrupt ecological change in the form of natural disasters; now it is also actualized around big, slow-moving change processes such as climate change, scenarios of future climate change, the globalization of economies, and demographic change, which shape the trajectories of communities worldwide. This widening of the resilience research field is reflected in new varieties of resilience, introducing new concepts-e.g., community resilience, information resilience, and cultural resilience. At this time, community resilience is one of the more prevalent resilience variants (Wilson, 2014).

Resilience in communities requires planning, mobilization of resources, organization, and use of adaptive capacities. Public libraries are among the most numerous of public institutions, and widespread in most sizable communities in most countries (OCLC, 2016). ${ }^{1}$ In addition to their place presence, or 'placeness', public libraries are among the most trusted public institutions nationally and in their local communities. Swedish public libraries provide the second most publicly trusted government service, nearly on a par with public health services (Höglund \& Wahlström, 2009), and in Norway, public libraries are the most trusted service, ahead of the police (Vårheim, 2014). Moreover, public libraries are generally viewed as highly safe places to be (Cox, Swinbourne, Pip, \& Laing, 2000; Miller, Zickuhr, Rainie, \& Purcell, 2013; Solop, Hagen, \& Bowie, 2007). Strong communal situatedness, in terms of physical infrastructure, institutional trust, and as providers of open accessible safe places, make libraries potentially interesting institutions in the study of community resilience. What is the present status of knowledge on public libraries in relation to community resilience and such related resiliencies as information resilience, community resilience, and cultural resilience?

\footnotetext{
${ }^{1}$ Adding up the number of public libraries in the 219 countries out of 238 countries with available data in the latest OCLC (The Online Computer Library Center) global library statistics, there are at least 291,813 public library systems in the world (OCLC, 2016). The number of public libraries is probably significantly higher due to the fact that the number of service points most probably vastly outnumbers the number of library systems, and data are unavailable (OCLC, 2016). In short, there are two main problems with number-of-library-units statistics: firstly, the branch problem, indicating confusion in the counting of public library systems vs. public library branches; secondly, the size problem, indicating that libraries below a non-specified and varying size do not count (i.e., are not counted and are accordingly not represented in the data) (Plinius, 2010). For these reasons, among others, there are good reasons for estimating the number of public libraries in the world significantly higher than the nearly 300,000 libraries mentioned above.
} 
In information policy research in general, and in public library research, very little resilience research has been conducted. ${ }^{2}$ Derived resilience concepts such as community resilience and information resilience have been applied to a very limited extent, and primarily in relation to the role of public libraries in disasters and in information literacy initiatives toward refugees.

Expanding upon previous work on public libraries (Vårheim, 2015, 2017), this short paper presents relevant resilience research to provide a basis for further research for developing theoretical concepts on the role of public libraries in contributing to community resilience and community development. Concepts such as community resilience, information resilience, and cultural resilience are introduced, affording a condensed introduction to the literature on public libraries and resilience in general, while focusing on the derived concepts of community resilience, information resilience, and cultural resilience. It is argued that public libraries are particularly suited for community resilience research.

\section{Concepts of Resilience}

Resilience theory originated in physics with the description of a material's ability to bounce back to its former state, achieving equilibrium after experiencing external stressors. The re-establishing of equilibrium is common to early definitions: earlier formulations defined resilience as "the capacity of a material or system to return to equilibrium after a displacement" (Norris et al., 2008, p. 127). Later formulations stress the ability of human systems to adapt to external pressures and disturbances through learning processes, modifying or changing systems and thereby strengthening the response to factors threatening system survival-i.e., making the system more resilient by developing "a capacity for successful adaptation in the face of disturbance, stress, or adversity" (Norris et al., 2008, p. 129).

Resilience theory distinguishes between general resilience and specified resilience according to prior knowledge of expected system disturbances (Folke, Carpenter, Walker, Scheffer, Chapin, \& Rockström, 2010). Specified resilience is directed toward specific expected, more or less abrupt major events (e.g., tornados or an ageing population). Generalized resilience describes a capacity to handle unexpected events and uncertainty in general. It covers unknown and improbable system threats.

Specified resilience needs to be balanced relative to general resilience. Specific threats are more easily turned into institutionalized structures, prescribing

\footnotetext{
${ }^{2}$ In a search for "public librar*" AND resilience in title and abstract fields of LISTA (Library, Information Science and Technology Abstracts), Scopus, and Web of Science, five possibly relevant journal articles were found; even lower numbers were found when searching for "information resilience" and "cultural resilience".
} 
future general resilience efforts for facing novel threats. Thus, unbalanced specified resilience is not resilient. The wide scope of generalized resilience makes it difficult to define precise resilience applications. However, Carpenter et al. (2012, p. 3252) identify nine different factors that may influence the building of general resilience resources: diversity, feedback, leadership, modularity, monitoring, nestedness, openness, reserves, and trust. For resilience to remain general, institutions need options for self-regulation and innovation (Carpenter et al., 2012, p. 3255).

The contribution of public libraries to resilience is mediated through different resiliencies, both specified and general in character, and related to different roles of public libraries. In this paper, the three main library roles or library service areas and their connections are related to three established concepts of resilience directly applicable to library functions.

\section{Public Library Resiliencies}

Typical public library mission statements highlight the community building role of public libraries: "The Denver Public Library connects people with information, ideas and experiences to provide enjoyment, enrich lives and strengthen our community" (Denver Public Library, 2016). This means that public libraries are aware that their local community presence gives them a prominent role in community development and in creating community resilience. More specifically, while the informational/educational and cultural activities of libraries relate to goals of learning and cultural experience, both kinds of activity are connected to the local community, and can be seen as strengthening both the resilience of the community and specific resiliencies related to information and culture.

\section{Community Resilience}

The concept of community resilience is central within the two dominant theoretical perspectives of the human systems resilience literature (Berkes \& Ross, 2013). The first perspective is social ecology, while the second contains various social science fields arising from developmental psychology and mental health, and is the footing of resilience in disaster research. Community resilience can be defined as "the existence, development, and engagement of community resources by community members to thrive in an environment characterized by change, uncertainty, unpredictability, and surprise" (Magis, 2010, p. 402). Cutter et al. (2008, p. 599) define communities as "the totality of social system interactions within a defined geographic space such as a neighborhood, census tract, city, or county".

Norris et al. (2008) developed a much used theoretical model to 
understand community resilience as a process connecting four types of adaptive capacity toward the goal of community adaptation: community competence, economic development, information and communication, and social capital. This model provides a strategy for being ready when disaster, in the form of abrupt events, strikes. It shares the disaster focus with much of the relevant community resilience literature. At the same time, the authors stress that the idea is to provide a model for meeting unknown threats - i.e., the model contains a general resilience component.

In addition to social capital, the community resilience literature lists several other community resources or community capitals as important variables giving rise to community resilience (Aldrich, 2012; Miles, 2015; Wilson, 2014). For example, Wilson (2014, p. 6) applies three community capitals as "key resilience drivers": social capital, economic capital, and environmental capital. Aldrich (2012) makes social capital the main factor for increasing community resilience and for disaster recovery.

\section{Public Libraries and Community Resilience}

The literature on public libraries and community resilience is limited, with only two studies using the concept for analytical purposes. Veil and Bishop (2014), in their study on how public libraries worked during natural disasters (mainly tornados in selected U.S. states), applied a community resilience theoretical perspective based on the framework developed by Norris et al. (2008). The findings point to several ways in which libraries increased community resilience and helped disaster recovery. Public libraries provided the only information access to the outside world, a meeting and working space for locals and relief organizations, a repository for local information, and a place for telling and collecting people's disaster narratives. A few papers on the efforts of libraries during disasters (e.g., Jaeger, Langa, McClure, \& Bertot, 2006; Vårheim, 2015), while not using a community resilience framework, found that libraries were among the few organizations that actually worked in the recovery processes, thus demonstrating the community resilience potential of libraries. Grace and Sen (2013) use community resilience in a case study on public library daily work practices, exploring how a public library increases or decreases community resilience; they state that community resilience is of vital importance in maintaining library relevance in a world of change.

\section{Information Resilience}

Hersberger (2011) applies resilience theory to information studies. Her focus is on how libraries and information professionals with more knowledge of barriers and 
bridges for user information behavior can increase the information resilience of individual users by developing more targeted services enhancing user information-seeking skills. Lloyd (2015) explicitly uses information resilience, develops its definition and conceptual implications, and shows its fruitfulness in different social practice contexts, including workplace settings (Lloyd, 2013) and health literacy among refugees (Lloyd, 2014). Social networks within a social capital theoretical framework are used as a way of explaining how resilience originates, while public libraries are portrayed as safe and tolerant places, suitable for increasing information literacy and information resilience among disadvantaged social groups (Lloyd, 2015).

\section{Cultural Resilience}

Cultural resilience refers to the impact of culture-specific values and customs on adaptation to major change. The cultural resilience literature can be divided into three strands: a socio-ecological theoretical perspective; a social psychology and healthcare perspective (Rotarangi \& Stephenson, 2014); and a cultural heritage activities and organizations perspective (Beel et al., 2015), including local cultural economy capacity building (Pratt, 2015). Social psychological approaches generally concentrate more on individual resilience strategies of adaptation to change than the two other perspectives, which tend to be society and community oriented.

From a socio-ecological theoretical perspective, Crane defines cultural resilience "as the ability to maintain livelihoods that satisfy both material and moral (normative) needs in the face of major stresses and shocks; environmental, political, economic, or otherwise" (2010, p. 2). A study of reindeer nomads in Russia shows how cultural factors contribute to the resilience of socio-ecological systems (Forbes, 2013). Social-psychological and healthcare studies focus on how resilient cultural aspects may strengthen positive health outcomes for individuals and communities. Bals, Turi, Skre, and Kvernmo (2011) identified mental health protective cultural variables among Sami youths. Another study into health inequalities among gay men suggests that integrating resilience thinking into healthcare initiatives for health promotion could lead to better health outcomes (Herrick, Friedman, \& Stall, 2012).

Place (locally) based identities created and consolidated through cultural heritage activities expressed through voluntary organizations (local history societies) and heritage institutions (local museums) can contribute to local cultural resilience, and by doing so contribute to building collective resilience and community resilience (Beel et al., 2015). In the same vein, maintenance of historical buildings and adjacent community activities, such as festivals and voluntary association meetings, co-produce local identity and community 
resilience.

In accordance with the cultural resilience/community impact of cultural heritage institutions, public libraries are well-placed in local communities for building cultural resilience. Libraries provide literature, cultural events, and a meeting space for cultural voluntary and heritage organizations. However, few, if any, studies of the contribution of public libraries to cultural resilience have been conducted.

\section{Discussion}

Having identified some of the empirical and theoretical perspectives of resilience research and the role of public libraries in creating resilience in their communities, this paper calls for further ideas and critiques for development of an agenda for conceptual exploration and research. The concepts of community resilience, information resilience, and cultural resilience are all within the traditional remit of public libraries. The concept of the modern public library has proved resilient over time. However, how and to what extent public libraries actually contribute to social resilience is an empirical question, and outside of disaster situations, largely remains to be seen; very few studies relating to this substantive role of public libraries have been conducted.

\section{References}

Aldrich, D. P. (2012). Building resilience: Social capital in post-disaster recovery (Kindle version). Chicago: University of Chicago Press.

Bals, M., Turi, A. L., Skre, I., \& Kvernmo, S. (2011). The relationship between internalizing and externalizing symptoms and cultural resilience factors in Indigenous Sami youth from Arctic Norway. International Journal of Circumpolar Health, 70(1). doi.org/10.3402/ijch.v70i1.17790

Beel, D. E., Wallace, C. D., Webster, G., Nguyen, H., Tait, E., Macleod, M., \& Mellish, C. (2015). Cultural resilience: The production of rural community heritage, digital archives and the role of volunteers. Journal of Rural Studies, 1-10. doi.org/10.1016/j.jrurstud.2015.05.002

Berkes, F., \& Ross, H. (2013). Community resilience: Toward an integrated approach. Society \& Natural Resources, 26(1), 5-20. doi.org/10.1080/08941920.2012.736605

Carpenter, S. R., Arrow, K. J., Barrett, S., Biggs, R., Brock, W. A., Crépin, A.-S., ... de Zeeuw, A. (2012). General resilience to cope with extreme events. Sustainability, 4(12), 3248-3259. doi.org/10.3390/su4123248

Cox, E., Swinbourne, K., Pip, C., \& Laing, S. (2000). A safe place to go: Libraries and social capital (p. 53). Sydney: University of Technology, 
Sydney, and the State Library of New South Wales. Retrieved from http:// www.sl.nsw.gov.au/services/public_libraries/docs/safe_place.pdf. (Archived by WebCite ${ }^{\circledR}$ at http://www.webcitation.org/6kFayNC8r)

Crane, T. A. (2010). Of models and meanings: Cultural resilience in socialecological systems. Ecology and Society, 15(4), 19. Retrieved from http://www.ecologyandsociety.org/vol15/iss4/art19/

Cutter, S. L., Barnes, L., Berry, M., Burton, C., Evans, E., Tate, E., \& Webb, J. (2008). A place-based model for understanding community resilience to natural disasters. Global Environmental Change, 18(4), 598-606. doi.org/10.1016/j.gloenvcha.2008.07.013

Denver Public Library. (2016). Mission \& strategic plan | Denver Public Library. Retrieved from https://www.denverlibrary.org/content/about-dpl. (Archived by WebCite ${ }^{\circledR}$ at http://www.webcitation.org/6m7UekuZX).

Folke, C., Carpenter, S. R., Walker, B., Scheffer, M., Chapin, T., \& Rockström, J. (2010). Resilience thinking: Integrating resilience, adaptability and transformability. Ecology and Society, 15(4), 20. Retrieved from http://dlc.dlib.indiana.edu/dlc/handle/10535/7422

Forbes, B. C. (2013). Cultural resilience of social-ecological systems in the Nenets and Yamal-Nenets autonomous Okrugs, Russia: A focus on reindeer nomads of the tundra. Ecology and Society, 18(4). doi.org/10.5751/ES-05791-180436

Grace, D., \& Sen, B. (2013). Community resilience and the role of the public library. Library Trends, 61(3), 513-541. doi.org/10.1353/lib.2013.0008

Herrick, A. L., Friedman, M. S., \& Stall, R. (2012). Gay men's health and the theory of cultural resilience. In C. J. Patterson \& A. R. D'Augelli (Eds.), Handbook of psychology and sexual orientation (pp. 191-203). Oxford University Press. Retrieved from http://www.oxfordscholarship.com/ view/10.1093/acprof:oso/9780199765218.001.0001/acprof9780199765218-chapter-14

Hersberger, J. (2011). Resilience theory, information behaviour and social support in everyday life. Proceedings of the Annual Conference of CAIS / Actes Du Congrès Annuel de l'ACSI, 7. Retrieved from http://www.caisacsi.ca/ojs/index.php/cais/article/view/273

Höglund, L., \& Wahlström, E. (2009). Användningen och attityderna. En rapport om allmänhetens användning av och syn på folkbibliotek baserad på SOM-undersökningen 2007. [Use and attitudes: a report on use and views on public libraries based on the 2007 SOM-survey]. (Svensk Biblioteksförenings rapporter No. 13). Stockholm, Sweden: Svensk Biblioteksförening. Retrieved from http:/hb.diva-

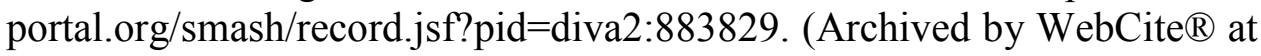
http://www.webcitation.org/6m7RWqtZ2) 
Jaeger, P. T., Langa, L. A., McClure, C. R., \& Bertot, J. C. (2006). The 2004 and 2005 Gulf Coast hurricanes: Evolving roles and lessons learned for public libraries in disaster preparedness and community services. Public Library Quarterly, 25(3-4), 199-214. doi.org/10.1300/J118v25n03_17

Lloyd, A. (2013). Building information resilient workers: The critical ground of workplace information literacy. What have we learnt? In S. Kurbanoğlu, E. Grassian, D. Mizrachi, R. Catts, \& S. Špiranec (Eds.), Worldwide commonalities and challenges in information literacy research and practice (pp. 219-228). Springer International Publishing. doi.org/10.1007/978-3-319-03919-0_28

Lloyd, A. (2014). Building information resilience: How do resettling refugees connect with health information in regional landscapes? Implications for health literacy. Australian Academic \& Research Libraries, 45(1), 48-66. doi.org/10.1080/00048623.2014.884916

Lloyd, A. (2015). Stranger in a strange land: Enabling information resilience in resettlement landscapes. Journal of Documentation, 71(5), 1029-1042. doi.org/10.1108/JD-04-2014-0065

Magis, K. (2010). Community resilience: An indicator of social sustainability. Society \& Natural Resources, 23(5), 401-416. doi.org/10.1080/08941920903305674

Miles, S. B. (2015). Foundations of community disaster resilience: Well-being, identity, services, and capitals. Environmental Hazards, 14(2), 103-121. doi.org/10.1080/17477891.2014.999018

Miller, C., Zickuhr, K., Rainie, H., \& Purcell, K. (2013). Parents, children, libraries, and reading. Washington, D.C.: Pew Research Center's Internet \& American Life Project.

Norris, F. H., Stevens, S. P., Pfefferbaum, B., Wyche, K. F., \& Pfefferbaum, R. L. (2008). Community resilience as a metaphor, theory, set of capacities, and strategy for disaster readiness. American Journal of Community Psychology, 41(1-2), 127-150. doi.org/10.1007/s10464-007-9156-6

OCLC. (2016). Global library statistics. Retrieved from https://www.oclc.org/global-library-statistics.en.html. (Archived by WebCite $\AA$ at http://www.webcitation.org/6m7RAwl00)

Plinius. (2010, August 14). ST 34/10: How many libraries? Retrieved from https://iflastat.wordpress.com/2010/08/14/how-many-libraries/. (Archived by WebCite ${ }^{\circledR}$ at http://www.webcitation.org/6m7QvjyXt)

Pratt, A. C. (2015). Resilience, locality and the cultural economy. City, Culture and Society, 6(3), 61-67. doi.org/10.1016/j.ccs.2014.11.001

Rotarangi, S. J., \& Stephenson, J. (2014). Resilience pivots: Stability and identity in a social-ecological-cultural system. Ecology and Society, 19(1). doi.org/10.5751/ES-06262-190128 
Solop, F. I., Hagen, K. K., \& Bowie, J. I. (2007). Survey of Arizonans' attitudes about public libraries: Fall 2006. Flagstaff, AZ: Northern Arizona University, Social Research Laboratory. Retrieved from http://azmemory.azlibrary.gov/cdm/ref/collection/statepubs/id/3879. (Archived by WebCite ${ }^{\circledR}$ at http://www.webcitation.org/6kFgDvZUf)

Vårheim, A. (2014). Trust in libraries and trust in most people: Social capital creation in the public library. The Library Quarterly, 84(3), 258-277. doi.org/10.1086/676487

Vårheim, A. (2015). Public libraries worked in the Tohoku mega-disaster. Proceedings from the Annual Meeting of the Document Academy, 2(1), 111. Retrieved from http://ideaexchange.uakron.edu/docam/ vol2/iss1/10. (Archived by WebCite ${ }^{\circledR}$ at http://www.webcitation.org/6m7QQMWv3)

Vårheim, A. (2017). Public libraries, community resilience, and social capital. Information Research, 22(1).

Veil, S. R., \& Bishop, B. W. (2014). Opportunities and challenges for public libraries to enhance community resilience. Risk Analysis, 34(4), 721-734. doi.org/10.1111/risa. 12130

Wilson, G. A. (2014). Community resilience: Path dependency, lock-in effects and transitional ruptures. Journal of Environmental Planning and Management, 57(1), 1-26. doi.org/10.1080/09640568.2012.741519 